University of Warwick institutional repository: http://go.warwick.ac.uk/wrap

This paper is made available online in accordance with publisher policies. Please scroll down to view the document itself. Please refer to the repository record for this item and our policy information available from the repository home page for further information.

To see the final version of this paper please visit the publisher's website. Access to the published version may require a subscription.

Author(s): Mah, Alice

Article Title: Moral judgements and employment policies in Birmingham (1870-1914) : multiplying the categories and treatments of the "undeserving"

Year of publication: 2009

Link to published article :

http://dx.doi.org/10.1108/01443330910999023

Publisher statement: First published by Emerald in International Journal of Sociology and Social Policy. Mah, A. (2009). "Moral judgements and employment policies in Birmingham (1870-1914): multiplying the categories and treatments of the "undeserving"", International Journal of Sociology and Social Policy, 29(11/12), pp. 575 - 586. 


\title{
Moral judgements and employment policies in Birmingham (1870-1914): multiplying the categories and treatments of the 'undeserving' [1]
}

\author{
Dr Alice Mah \\ Department of Sociology \\ University of Warwick \\ Coventry CV4 7AL
}

a.a.mah@warwick.ac.uk

\begin{abstract}
Purpose - The purpose of this paper is to analyse the justifying arguments of various Birmingham organisations between 1870 and 1914 in classifying and treating the unemployed. Using a capability approach, the paper will examine how employment policies in Birmingham during this period promoted or limited capabilities of work, life and voice. Finally, implications for labour market policies today will be discussed.
\end{abstract}

Design/methodology/approach - The theoretical framework for this paper will draw on the capability approach to a person's well-being developed by Amartya Sen and on theoretical and empirical developments of the capability approach by other authors such as Bonvin and Salais. This paper is based on historical archival research and analysis.

Findings - Birmingham was an exemplar of municipal social reform in late nineteenth century England, with the development of a range of public services including education, electricity and public transport. However, the city's vision of civic reform was closely connected to the Liberal market logic of individual responsibility, and moral judgements of the unemployed served to multiply the categories and punitive treatments of the "undeserving", separating the valid from the invalid citizen.

Originality/value - This case study of municipal employment policies in Birmingham at the turn of the twentieth century demonstrates the implications of moral judgements, classifications and treatments of the unemployed for people's capabilities in work and life, drawing connections to discourses of responsibility and citizenship today. 
Keywords - Unemployment, Sociology of work, Social policy, Labour market, Economic history, United Kingdom

Attempts have been made... to provide for the relief of the deserving man out of work, but these attempts have failed because of the difficulty of finding suitable work, and further because the selection of the deserving has been found too difficult and exacting a duty for the bodies elected for the purpose to thoroughly carry out. (Muirhead, 1911, p. 470-71).

\section{Introduction}

Labour market policies in the United Kingdom have long been marked by the legacy of the Poor Laws, which assumed that poverty due to lack of work was the consequence of individual moral weakness rather than economic structural factors. Lack of thrift and indolence were thought to characterise the vast majority of the poor, and all recipients of Poor Law relief were subject to disenfranchisement, stigmatisation and admission to the workhouse where conditions were as harsh as in the average penitentiary. Unemployed people were classified under the Poor Laws as 'able-bodied' men, with the implication that they were able to work but lacked the thrift and discipline to find and keep work. As such, their receipt of 'indoor relief' (inside the workhouse) or where sanctioned 'outdoor relief' (outside of the workhouse in labour yards or public works) was conditional upon completion of labour tasks such as stone-breaking, oakum-picking and wood-chopping. The underlying principle of the Poor Laws was that the able-bodied poor 'on the whole shall not be made really or apparently as eligible as the situation of the independent labourer of the lowest class'(Beveridge, 1930, p. 150). Labour for the able-bodied through Poor Law relief was thus intentionally punitive: it generally went unremunerated, it reduced rather than enhanced existing skills, and, for the respectable worker, it damaged his moral standing as he was forced to associate with the 'unemployable'.

Labour market policies in Britain between 1870 and 1914 developed from: 1) punitive Poor Law measures dating from the Poor Law reform of 1834 which encompassed the destitute unemployed as part of the 'undeserving' poor; to 2) experiments in relief of the non-pauperised unemployed by different agencies from the 1880s, consolidated 
under the Unemployed Workmen Act of 1905; to 3) the national development of Labour Exchanges in 1909 as a more efficient means of linking employers with these 'deserving' unemployed; and finally, to 4) the development of national unemployment insurance in 1911 designed to offer a permanent distinction between the pauper and the unemployed that obliged regular workers in specific trades to save against unemployment. Despite differences in defining, classifying and treating the 'unemployed', there was remarkable moralising continuity between these policies in the concepts of deserving and undeserving, the emphasis on thrift and self-help, and the principle of less eligibility. These concepts of the 'unemployed' have remained embedded in British employment policies, particularly in the era leading up to the First World War, and they are arguably still visible in 'welfare-to-work' policies today.

At the turn of the twentieth century, the aim was to separate out the socially assisted from the unemployed. At the turn of the twenty-first century in the United Kingdom, the socially assisted and the unemployed have instead been amalgamated: Jobcentre Plus was formed in April 2002 to bring together the services of the Benefits Agency and the Employment Service. Jobcentre Plus has been criticised for prioritising rapid job placement over quality of employment and for privileging 'work' over 'welfare' responsibilities (Karagiannaki, 2007), reflecting the liberal, market-oriented welfareto-work policy context in the United Kingdom (Carpenter et al., 2007, Peck, 2001). With the development of Jobcentre Plus, 'the apparent gains in insulation from stigmatizing governmental regimes are bought at the price of more subtle and individualized inscriptions of 'failure' onto unemployed subjectivity' (Cole, 2007, p. 130). Although there was a shift away from overt stigmatisation of unemployment in the first half of the twentieth century towards treating unemployed people as workerconsumers through the discourse of 'jobseekers', moral judgements of the unemployed continue in current policy discourses, with euphemisms such as "poorly motivated' replacing the concept of the 'undeserving'. As Cole (2007, p. 143) argues, '(t)he moral stigmatization of flawed workers remains, but has been redoubled and to an extent obfuscated by the contemporary discursive valorization of consumption'.

This paper will focus on municipal employment policies, moral judgements and classification criteria of the unemployed through the case study of Birmingham 
between 1870 and 1914, a leading example of municipal social reform in late nineteenth century Britain. The research methodology involves analysis of historical published and unpublished materials including archival records from the Modern Records Centre (University of Warwick), Birmingham City Archives, and the Parliamentary Papers in the Bodleian Library. The analytical framework draws on the capability approach of Amartya Sen (1993), following theoretical developments articulated by Salais and Villeneuve (2004) and Bonvin and Orton (Introductory article in this issue). This paper will argue firstly that municipal organisations cooperated to some extent on the issue of 'unemployment' but that they did not succeed in organising the labour market; secondly, that municipal organisations' employment policies were based on shared moral assumptions and judgements about the 'undeserving' and the 'deserving' poor; and thirdly, that the effect of municipal employment policies was to multiply the categories and treatments of the 'undeserving', resulting in varying degrees of punishment. Finally, this paper will discuss implications of this research for developing policies which enhance people's capabilities in work and life, drawing parallels with labour market policies today.

\section{Birmingham in historical context}

Birmingham has been described as 'the city of a thousand trades' and as 'the great toyshop of Europe' (cf. Briggs, 1952, Hennock, 1973, Upton, 1993). In the first half of the nineteenth century, Birmingham was a city with a distinctive industrial atmosphere characterised by close relations between skilled masters and craftsmen. The four main trades in Birmingham during this period were guns, jewellery, buttons and brass, and industry operated through a number of small workshops. Birmingham grew rapidly in size and population, from 70,000 at the first census of 1801 to over a million at the census of 1931 (Briggs, 1952, p. 9). During the Industrial Revolution in the second half of the nineteenth century, the industrial structure in Birmingham began to change, with a shift from small workshops to large-scale factories and the emergence of new industries such as cycle manufacture, electrical industries and motor cars. The period between 1870 and 1914 in Birmingham was characterised by the migration of industry to the outskirts of the city centre and by the growth of new industrial districts on the city fringe (Wise and Thorpe, 1950, p. 213). By 1914, the industrial organisation had been radically transformed because of the increased scale 
of local enterprises and the changes in their location to the suburbs. Social relations between employees and employers became less intimate, but 'the tradition of skill, the variety of trades, and the adaptability of the finishing industries' remained prominent features of the city's industrial atmosphere well into the twentieth century (Briggs, 1952, p. 5).

The 1870s municipal reform movement in Birmingham has been heralded as a success story of civic transformation (Briggs, 1952, Hennock, 1973, Muirhead, 1911). The reform movement was rooted in Non-conformist religious ideas about civic responsibility and liberal market ideas of free enterprise. As Hennock (1973, p. 172) argues, the crucial innovation of the Birmingham municipal reform movement was 'a new vision of the function and nature of the corporation.' Following the national Municipal Corporations Act of 1835, 'Corporation' was used interchangeably with 'City Council', giving the term 'Corporation' a dual meaning in the context of Birmingham's entrepreneurial vision of civic reform. Joseph Chamberlain, who served as mayor for Birmingham between 1873 and 1876, was the principal figure associated with the municipal civic transformation. During his three years in office, Chamberlain was responsible for three main achievements: the municipalisation of gas, the taking over of the water supply and the City Improvement Scheme. The municipalisation of gas and water enabled people to have access to an efficient power supply and clean and affordable water, and the provision of these services was also profitable for the city. The development of municipal trading paved the way for further civic reforms in education, transport and electricity. By contrast with municipal trading, the City Improvement Scheme was concerned primarily with the construction of Corporation Street, the most controversial civic 'improvement' because it involved extensive slum clearances of working class homes which the city for the most part neglected to replace. Chamberlain continued to play a role in local politics as M.P. for Birmingham between 1876 and his death in 1914, and as president of the Local Government Board from 1886. Chamberlain's crowning achievement was the founding of Birmingham University in 1900, England's 'first civic university' (Ives et al., 2000). In general, Chamberlain was seen as a visionary municipal leader both nationally and internationally; in 1890 Birmingham was described as the 'bestgoverned city in the world' in Harper's Monthly Magazine (Ralph, 1890). 
The Liberal ideal of individual freedom which defined the municipal reform movement in 1870s Birmingham can be analysed through the lens of the capability approach (cf. Bonvin et al., 2006, Salais, 2004, Sen, 1993). The Victorian notion of 'self-help' played a large role in shaping the Liberal approach to people's 'capabilities' in work and life: people should be given the means to develop themselves through the provision of public services such as an adequate power supply, an efficient public transport system, access to clean water, and access to education. The establishment of educational institutions for the 'working man' in close collaboration with local industry in Birmingham was a positive example of how the Corporation conceived of enabling capabilities. Birmingham University developed innovative courses in practical applied science and commerce, notably the British School of Malting and Brewing and the Practical Mining School (Ives et al., 2000). Another way that the Corporation enabled capabilities for working people was through public transport: the municipalisation of the tramways in 1911 provided greater mobility and cheap public transport for at least the wealthier working classes.

However, once the Corporation had provided services for the public, people had to take responsibility for their own successes and failures in work and life. To use the language of the capability approach (cf. Salais, 2004), no 'conversion factors' from resources to capabilities were provided for people to help them take advantage of these services, and many barriers actually inhibited the poorest working classes from benefiting from them. When the logic of the market did not coincide with the logic of civic responsibility, the market logic tended to prevail, and this was most obvious in relation to the social exclusion of the 'undeserving' poor. One of the most glaring omissions of the Corporation was its reluctance to provide adequate and sanitary housing for the working poor. The Corporation was also slow to tackle the social question of the unemployed as indeed it was reluctant to address any labour market issue directly. This was in keeping with national trends in labour market policy at the time, for the social question of pauperism and the unemployed only became a pressing national question of industrial inefficiency by 1909 (Harris, 1972). The public authorities in Birmingham were reluctant to take responsibility for the unemployed as a separate category from the 'undeserving' poor, leaving a strong role for civil agencies such as trade unions, friendly societies and charities in providing relief and benefits for the unemployed. 


\section{Municipal employment policies and organisational cooperation}

There were a range of different organisations for dealing with the unemployed in Birmingham between 1870 and 1914. In general, the organisations cooperated with one another on issues of unemployment although conflicts arose over strategies, methods and responsibilities for dealing with the unemployed. Despite their differences, governmental and civil organisations in Birmingham shared a moralising framework based on notions of self-help, thrift, hard work and responsibility that separated the 'undeserving' from the 'deserving' and proved to be a strong barrier for the majority of the poor and the unemployed in developing any 'capabilities' in work or life.

\section{Governmental organisations}

In accordance with the Poor Laws, any able-bodied person who applied to the Poor Law Guardians for poor relief was disenfranchised, and outdoor relief (outside of the workhouse) was only granted subject to the performance of a labour test, although widows were treated with greater leniency. Boards of Guardians were set up to administer the Poor Law in each municipality, and Guardians were elected by owners of property who paid the poor rate. The Guardians provided outdoor relief in Birmingham only in a few cases. For example, a stone yard was opened in the winters of 1878-79 and 1879-1880 to serve as a labour test to men on outdoor relief, but the Guardians felt that this was unsuccessful, for: 'in the majority of the cases the quasi stone-breakers stood round large fires during the greater part of the day, and in the evening received their relief for the mere shadow of labour...' [2]

The function and interests of the Board of Guardians were separate from the Birmingham Corporation, as the Guardians were elected specifically to address the issue of poor relief, and the Corporation had no official role in this regard. The differences between the two are perhaps best illustrated by the events of 1885 during a period of extreme depression across many of the trades in Birmingham. At the start of this year, the Corporation set up a 'Mayor's Fund' for the relief of the unemployed, but it was unsuccessful in its attempts to make work for men. [3] In July 1885, the 
General Purposes Committee of the Corporation requested a conference with the Board of Guardians to propose collaborative efforts on the issue of distress. The Guardians refused to cooperate, arguing that 'the ordinary Poor Law is capable of dealing with the matter as it at present stands.'[4] Joseph Chamberlain appealed directly to the Board of Guardians to reconsider their position, arguing that 'it was not possible for the Corporation to find work for any considerable number without displacing workmen already employed,' and that 'none but the appointed Guardians of the Poor' were in a position to deal with the issue of distress. Despite this appeal, the Guardians held their position, and they also refused to provide any form of outdoor relief.

In 1893, the General Purposes Committee considered the issue of work relief for the unemployed in the context of the upcoming winter, and it concluded that most employers would be reluctant to hire unemployed people to work in charitable employment because of the generally poor quality of unemployed workmen. Furthermore, the committee argued that relief of the poor was not the duty of the municipality, but rather the primary function of the municipality was to be economical and efficient. [5] In this way, the Committee removed itself from the responsibility of dealing with the unemployed. However, in the intervening years, the Birmingham Corporation did not remain entirely detached from the rising problem of unemployment. The City Aid Society was formed between 1902 and 1904 during a time of exceptional distress in the city, and it worked in collaboration with the Corporation, which opened a Lord Mayor's Fund in 1904-5 to deal with great distress. F. Tillyard, secretary of the Lord Mayor's Relief Fund in Birmingham in 1904-5, compared three poor relief funds in Birmingham in 1885, 1886, and 1905 (Tillyard, 1905). On the basis of his comparison of statistics for the different relief funds, he concluded that 'skilled artisans and respectable workmen generally are more provident' whereas 'many unskilled labourers, and the less respectable workmen, whether skilled or unskilled, are less provident and less independent than they were twenty years ago' (Tillyard, 1905, p. 506). Tillyard noted that there was thus 'an increasing moral weakening and degeneration of the inhabitants of the slums of the great city.' He pointed to a mounting crisis of unemployment at the turn of the century, where for the first time unemployment was seen not only as an issue of 
individual moral failure but as a threat to social, economic and moral security for the middle classes.

The Unemployed Workmen Act of 1905 was adopted by the Local Government Board, a national Government body which supervised laws relating to public health, the relief of the poor, and local government (between 1871 and 1919), to deal with the issue of distress from want of employment at the national level. Rather than presenting new policy the Act represented the '...formalization of the methods of relief independently developed by local, Poor Law, and charitable authorities' (Harris, 1972, p. 161). The Royal Commission on the Poor Laws was appointed just after the Act was passed, and the anticipation of the Commission's report underlined the limitations of the Act as an interim measure to deal with distress. The Birmingham Distress Committee was appointed under the Act of 1905, and it included eighteen members of the City Council, fourteen representatives of the Guardians, and eight 'persons experienced in the relief of distress, of whom one at least was to be a woman, chosen by the Council' (Vince, 1923).

The Board of Guardians continued to function after the establishment of the Distress Committee until 1930, at which point its administration passed to the city. After the establishment of the Birmingham Distress Committee, the Board of Guardians worked together with the Distress Committee in the treatment and classification of the able-bodied poor. In the winter of 1909, the Guardians set up a labour test yard and employed men with work in stone-breaking, wood-chopping and other manual tasks. The test yard was deemed a success, and several men were recommended to the Corporation Employment Exchange, a municipal labour exchange that had been set up to connect employers with the 'deserving' unemployed, for their good character while working on the yard. The Distress Committee found similar types of work for the unemployed through City Departments, mainly agricultural digging, excavations, and the preparation of land. Vince (1923, p. 496) notes in his History of the Corporation of Birmingham, 1900-1915 that the 'Unemployed Workmen Act had, in fact, debarred the Council from the view that the purposes for which it existed had no connection with the relief of distress'.

\section{Trade unions and friendly societies}


The Victorian notion of 'self-help' played a large role in shaping the Radical Liberal (Chamberlain) vision of how to treat the unemployed, and this ideology was shared by many of the trade unions and friendly societies in Birmingham. Hopkins (1995, p. 3) argues that working-class self-help in nineteenth-century Britain differed from the conventional definition of Victorian self-help in that: '(i)ts strongest characteristic was not individualism, but co-operation - especially working together to safeguard employment, and to make provision for sickness and ill-health'. However, trade unionism was relatively weak in late nineteenth-century Birmingham in comparison with other British cities, and the difference between Victorian and working-class selfhelp in this context was far less pronounced. Birmingham trade unions in this period generally stressed the importance of conciliation and cooperation in industry.

The Birmingham Trades Council was set up in 1866 to coordinate trade union activity in the city, and it had its own ideology of 'self-help':

[The Birmingham Trades Council]... worked to make the machinery of the state less class-dominated, it tried to get legislation to help the thrifty and industrious to rise out of the ranks of the wage-earners, and it supported or advocated the legal regulation of trades where the workers were too weak to fend for themselves. It was Chamberlainism with a cloth cap. (Corbett, 1966, p. 47)

Indeed, the close workplace relationships between masters and men 'produced an atmosphere and practice of class co-operation... [which] provided the basis for the attachment to Liberalism in general and to Chamberlain in particular, sustained by the Chamberlain legacy of municipal reform and social welfare' (Shackleton and Wright, 1983, p. ii). Trade union benefits enabled working people to safeguard against unemployment, sickness, old age and accidents, and these provisions were associated with independence. However, only wealthier workers could afford membership in trade unions and friendly societies, and thus these collective self-help measures were set up to defend 'not only against the employers but also against those workers who were unskilled' (Corbett, 1966, p. 79).

The role of trade unions and friendly societies in providing education was an important aspect of working class 'self-help', and educational provision also had a 
moral dimension. The National Society of Amalgamated Brassworkers was founded in Birmingham in April 1872 with over 5,000 members, and it offered out-of-work pay, sick allowances, funeral allowances, and other benefits to fully-paid members. [6] The first General Secretary of the Brassworkers, W.J. Davis, believed that trade societies played an important role in education. In the $3^{\text {rd }}$ Annual Report of Brassworkers, Davis described trade societies as 'the schools for teaching order and principles which are essential to the progress of mankind.' (Davis, 1875). In this statement, Davis emphasised the broader role of trade societies in imparting social values of 'order and principles' rather than simply as institutions for technical training. Similarly, C.C. Cooke, a member of the Birmingham Distress Committee and a Poor Law Guardian, stated in his evidence to the Royal Commission on the Poor Laws and Relief of Distress on $18^{\text {th }}$ March 1907 that 'the teaching and the moral effect of the friendly societies has been good, it has taught people to rely upon themselves and made them reluctant to apply for Poor Relief'. [7] Through their emphasis on thrift, hard work and self-reliance in their provision of benefits and their role in social and moral education, trade unions and friendly societies in Birmingham tended to reinforce rather than subvert governmental ideologies of individual responsibility rooted in the Poor Law.

The next section will examine municipal agencies' classifications and treatments of the unemployed, highlighting the strong links between municipal employment policies and moral judgements.

\section{Moral judgements: classifications and treatments of the unemployed}

The distinction between the 'deserving' and 'undeserving' is widely cited as a feature of nineteenth-century unemployment policy in the UK (Harris, 1972, Rose, 1985, Thane, 1984). In the 1880s, unemployment gradually became recognised as a problem connected with trade depressions; there was growing concern for sustaining the economic efficiency of skilled workers, for the good of society as a whole, rather than punishing individual failure. The word 'unemployment' was first formally defined in 1895 by J.A. Hobson, later to be re-defined and investigated by social surveyors such as Booth and Rowntree, Poor Law administrators, and municipal and national government agencies. Charles Booth's social survey Life and Labour of the People of 
London (Booth and Webb, 1891) identified the causes of poverty with both economic and individual failings, and Booth refused to separate personal from economic factors (Hennock, 1976). Towards the turn of the twentieth century, there remained an underlying tension between punitive Poor Law traditions and steps towards addressing 'unemployment' as a broad social and economic issue rather than exclusively as an issue of 'pauperism'.

The broad parameters of classification of the 'unemployed' in Birmingham were articulated in the replies of the Birmingham Distress Committee to the Royal Commission on the Poor Laws in 1909. [8] The Royal Commission asked a series of questions to each of the local authorities' distress committees, including questions about the effectiveness of the Unemployed Workmen Act of 1905, the methods of investigating cases of applicants in accordance with the Local Government Board Regulations, and the criteria for selection of applicants. Two answers in particular from the Birmingham Distress Committee are illustrative:

Q. Has it been found possible to give preference to particular classes of applicants in accordance with the Local Government Board Regulations, and, if so, to what extent?

Birmingham: Yes. About two-thirds of the selected applicants have been given preference in accordance with the Regulations of the Local Government Board. The applications of single men with no dependents have not been entertained, and during the past winter the average number of children per man selected for work was 3.2 .

Q. Is preference given to any classes of applications other than those specified in the Local Government Board Regulations?

Birmingham: To some extent preference has been given to men who had provided for themselves by joining thrift societies, Trade Unions, etc., and in cases where the investigating officer has reported that the home of the applicant has been clean and tidy and the wife and children well cared for.'

The replies articulate the criteria for worthy applicants: 1) men (no women are mentioned, which implies that they were not considered); 2) have dependents, preferably two or more; 3) have demonstrated 'self-help' through providing for themselves by joining thrift societies, trade unions, and so on; and 4) have clean and 
tidy homes with well-cared for families (which signalled that the wife was also worthy of help, suggesting a moral politics of hygiene). Family responsibility was an important part of the 'deserving' poor; although the male workers remained at centre stage, their wives also had to demonstrate 'deserving' qualities by running good households and caring for their children, in order for the men to qualify for relief.

C.C. Cooke, Poor Law Guardian and Member of the Birmingham Distress Committee, also distinguished between the 'deserving' and 'undeserving' able-bodied poor in the following evidence to the Royal Commission on the Poor Laws and Relief of Distress on $18^{\text {th }}$ March 1907:

Q. You would have two systems at work, one for the thrifty would you say?

A. One for those of known good character.

Q. And one for those not of good character? - A. Yes.

Q. Two entirely different systems? - A. Yes, I think the present workhouse is sufficient for the people who have been of a loose and indolent character.

Q. Then as to the able-bodied, have you any scheme? - A. The able-bodied I should like to see taken away from the workhouse altogether, or put into a workhouse that was a workhouse indeed, and not a home of rest. I think they ought to be put where there is strict supervision and enforced labour. [9]

In this exchange, Cooke is speaking about his function as a Poor Law Guardian rather than as a member of the Distress Committee, as one can see from the emphasis on 'able-bodied' rather than 'unemployed', and with his reference to the option of the workhouse. His statement highlights the blurring of boundaries between the Distress Committee and the Poor Law Guardians in practice. The two different 'systems' he sets out reflect moral judgements of the able-bodied poor, those of 'known good character' and those of a 'loose and indolent character'. The reference to indolence indicates that character is judged by self-discipline in relation to work. Hard labour for the able-bodied in the workhouse was similar to work imposed on convicted criminals, and this work was given as punishment rather than for the enhancement of skills or capabilities. 
Another member of the Birmingham Distress Committee, Robert H. Best, who was also Chairman of the West Division of the City Aid Society, expressed his view of how to classify the poor as follows:

I... think that help for the respectable deserving poor should be found by charitable persons.

The rich should maintain those poor persons of unblemished character who are in need through no fault of their own.

Those whose character is not unimpeachable should be helped by outdoor relief with disenfranchisement.

The thriftless and the lazy should go into indoor institutions for supervision with powers over their personal liberty.

The drunken and vicious should be confined in an institution of a penal nature, submitting to powers over their personal liberty. [10]

Mr. Best's evidence demonstrates most vividly the strong moral judgements upon the unemployed and the poor by a member of the Distress Committee, which had been set up to distribute relief to the deserving unemployed without the stigma of the Poor Laws. Nonetheless, Mr. Best recommends disenfranchisement for all except for 'unblemished' characters, and his moral compass goes beyond the dichotomy of the 'deserving' and the 'undeserving' to include the more colourful categories of the 'thriftless and lazy' and the 'drunken and vicious', both of whom he advocates penalising severely. Different measures of punishment and discipline are given to the different classes of 'undeserving'. In Mr. Best's scheme, only the 'undeserving' subjects are within the realm of public responsibility, as he recommends voluntary charitable help for the first two categories of the 'deserving'. This suggests that even after the establishment of the Distress Committee, public authority in Birmingham remained reluctant to take responsibility for more than the 'undeserving' through the traditional means of the Poor Laws, and thus a strong role for civil agency was sustained. Mr. Best's membership of both the Distress Committee and the City Aid Society shows an elision between the two roles, just as Mr. Cooke's membership combines the perspectives of the Distress Committee and the Guardians.

The moral judgements in classifying the poor and the unemployed as either deserving or undeserving, and either citizens or disenfranchised, significantly shaped 
employment policies in Birmingham as in the United Kingdom more generally. While the classification of the 'deserving' remained relatively narrow and fixed as a category, the classification of the 'undeserving' expanded to include various categories and punitive treatments. The issue of the 'unemployed' and the question of labour market organisation remained beyond the scope of public authority. The statements of members of the Distress Committee, the Board of Guardians and the City Aid Society demonstrate that despite their differences, these agencies shared assumptions which valued self-help, thrift, hard work and family responsibility, and placed blame on all but a few 'unimpeachable' individuals for their failure in the labour market. The statements also demonstrate a deeper connection to Poor Law traditions in municipal and charitable organisations than official policy might suggest.

\section{Conclusion}

Birmingham between 1870 and 1914 was uneven in its promotion of capabilities for people to achieve their goals in work and in life, and it hindered many people's capabilities for voice (Bonvin et al., 2006). In particular, the Corporation discriminated against the poorest working classes through moral judgements and punitive treatments of the 'undeserving'. Despite offering opportunities for individual advancement through the provision of public services, the Corporation actively avoided structuring labour markets, preferring incremental policies such as increases in outdoor relief schemes for the 'deserving' unemployed. Some improvements had positive effects for everyone, such as better sanitation, a clean and efficient water supply, better health, and affordable public transport. However, the poorer members of society, the 'undeserving' poor, were excluded from many of the benefits of public services.

The principal change in employment policies in the United Kingdom at the turn of the twentieth century was in the classification of the unemployed. Between the 1870s and the mid-1880s, those destitute from want of employment were stigmatised as part of the 'undeserving poor' and had to rely on worker's self-help (union members would rely on their union benefit rights) or else the harsh treatment of the Poor Laws. From the mid-1880s, a certain portion of the unemployed were deemed to be 'deserving' of outdoor relief: able-bodied men with wives and children who possessed a record of 
regular work, thrift and self-help - and whose behaviour conformed to middle class norms. The 'undeserving' poor were divided into different categories and treated with varying degrees of punishment and discipline. Men and women were morally judged according to different standards both within the 'deserving' and 'undeserving' cases: women were treated more leniently with respect to work, especially if they were widows, and the wives of 'deserving' claimants had to fulfil the role of good caretakers and housekeepers. Ultimately, rather than to allow the 'unemployed' a full identity, the effect of the unemployment debate was to multiply the different categories and treatments of the 'undeserving'.

This paper has analysed how moral judgements, classifications and treatments of the unemployed were connected with municipal employment policies of governmental and civil organisations in Birmingham between 1870 and 1914. The research has important policy implications for questions of citizenship and responsibility. Today, euphemisms such as 'low aspirations', 'poorly motivated', 'low expectations', 'culture of dependency' and 'culture of worklessness' (cf. Community and Local Government 2008) have replaced more overt moral discourses of the 'waster', the 'loafer' and the 'undeserving'. As Clarke (2005, p. 451) argues, 'New Labour's ideal citizens are moralized, choice-making, self-directing subjects... Responsible citizens make reasonable choices - and therefore 'bad choices' result from the wilfulness of irresponsible people, rather than the structural distribution of resources, capacities and opportunities.' Moral judgements and employment policies also have implications for capabilities in theory and practice. According to Sen (1993), the more capabilities a person has, the more effective freedom and choice she has to achieve her goals in life and work, resulting in a 'virtuous circle'. However, if people's capabilities are blocked, this can result in a 'vicious circle', as in the case of punitive treatments of the 'undeserving' unemployed in Birmingham at the turn of the twentieth century.

\section{Notes}

1. Research for this paper was funded by the European Commission FP 6 project CAPRIGHT. I would like to thank Noel Whiteside, Jean-Michel Bonvin, Michael Orton, John Clarke, Martin Heidenreich and two anonymous reviewers for their helpful comments on early drafts. 
2. Birmingham Daily Post, February 1, 1883. Cited in (1909) [Cd. 4499] Report of the Royal Commission on the Poor Laws and Relief of Distress, Parliamentary Papers, London, p. 1069.

3. Op. Cit., p. 1102.

4. (1884-1888) City of Birmingham General Purposes Committee Minutes, Dec 1884Nov 1888.

5. (1893) [C.7182] Report on Agencies and Methods for dealing with Unemployed, Parliamentary Papers, London, pp. 219-220.

6. (1910) Rules of the National Society of Brassworkers and Metal Mechanics, Birmingham.

7. (1909) [Cd. 4835] Royal Commission on the Poor Laws and Relief of Distress, Parliamentary Papers, London, p. 405.

8. (1909) [Cd. 4944] Replies by Distress Committees in England and Wales to Questions circulated on the subject of the Unemployed Workmen Act, 1905, Parliamentary Papers, London, pp. 51-57.

9. (1909) [Cd. 4835] Royal Commission on the Poor Laws and Relief of Distress, Parliamentary Papers, London, p.412.

10. Ibid., p. 741. 


\section{References}

Beveridge, W. H. B. (1930), Unemployment: A Problem of Industry, Longmans Green, London.

Bonvin, J.-M. and Farvaque, N. (2006), "Promoting capability for work: the role of local actors", Deneulin S., Nebel M. and Sagovsky N. (Eds.), The Capability Approach: Transforming Unjust Structures, Springer, Dordrecht, pp. 121-42.

Booth, C. and Webb, B. (1891), Labour and Life of the People of London, Williams and Norgate, London.

Briggs, A. (1952), History Of Birmingham, Volume II: Borough And City 1865-1938, Oxford University Press, Oxford.

Carpenter, M., Freda, B. and Speeden, S. (2007), Beyond The Workfare State: Labour Markets, Equalities And Human Rights, Policy Press, Bristol.

Clarke, J. (2005), “New Labour's citizens: activated, empowered, responsibilized, abandoned?", Critical Social Policy, Vol. 25 No. 4, pp. 447-463.

Cole, M. (2007), "From employment exchange to Jobcentre Plus: the changing institutional context of unemployment", History of the Human Sciences, Vol. 20 No. 4, pp. 129-146.

Communities and Local Government (2008), “Aspiration and attainment amongst young people in deprived communities", Social Exclusion Task Force, Cabinet Office, London.

Corbett, J. (1966), The Birmingham Trades Council, 1866-1966, Lawrence \& Wishart, London.

Davis, W. J. (1875), National Society of Amalgamated Brassworkers Third Annual Report, Birmingham.

Harris, J. (1972), Unemployment and Politics: A Study in English Social Policy, 18861914, Clarendon Press, Oxford.

Hennock, E. P. (1973), Fit and Proper Persons: Ideal and Reality in NineteenthCentury Urban Government, Edward Arnold, London.

Hennock, E. P. (1976), "Poverty and social theory in England: the experience of the Eighteen-Eighties", Social History, Vol. 1 No. 1, pp. 67-91.

Hopkins, E. (1995), Working-Class Self-Help in Nineteenth Century England: Responses to Industrialization, UCL Press, London. 
Ives, E. W., Schwarz, L. D. and Drummond, D. K. (2000), The First Civic University: Birmingham 1880-1980, University of Birmingham Press, Birmingham.

Karagiannaki, E. (2007), "Exploring the effects of integrated benefit systems and active labour market policies: evidence from Jobcentre Plus in the UK", Journal of Social Policy, Vol. 36 No. 2, pp. 177-195.

Muirhead, J. H. (1911), Birmingham Institutions, Cornish Brothers, Birmingham.

Peck, J. (2001), Workfare States, Guilford Press, New York.

Ralph, J. (1890), “The best-governed city in the world”, Harper's Monthly Magazine, June, pp. 99-110.

Rose, M. E. (1985), The Poor and the City: The English Poor Law in its Urban Context, 1834-1914, Leicester University Press, Leicester.

Salais, R. (2004), "Incorporating the capability approach into social and employment policies", Salais, R. and Villeneuve, R. (Eds.), Europe and the Politics of Capabilities, Cambridge University Press, Cambridge, pp. 283-300.

Salais, R. and Villeneuve, R. (2004), Europe and the Politics of Capabilities, Cambridge University Press, Cambridge.

Sen, A. K. (1993), "Capability and well-being”, Sen, A. K. and Nussbaum, M. C. (Eds.), The Quality of Life, Oxford University Press, Oxford, pp. 30-53.

Shackleton, R. and Wright, A. (1983), Worlds of Labour: Essays in Birmingham Labour History, University of Birmingham Department of Extramural Studies.

Thane, P. (1984), “The working class and state 'welfare' in Britain, 1880-1914”, The Historical Journal, Vol. 27 No. 4, pp. 877-900.

Tillyard, F. (1905), "Three Birmingham relief funds-1885, 1886, and 1905", The Economic Journal, Vol. 15 No. 60, pp. 505-520.

Upton, C. (1993), A History of Birmingham, Phillimore, Chichester.

Vince, C. A. (1923), History of the Corporation of Birmingham, Volume IV, 19001915, Birmingham.

Wise, M. J. and Thorpe, P. O. (1950), "The growth of Birmingham 1800-1950", Kinvig, R. et. al. (Eds.), Birmingham and its Regional Setting, British Association Local Executive Committee, Birmingham, pp. 213-248. 